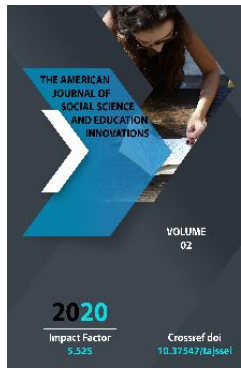

Journal Website: http://usajournalshub.c om/index,php/tajssei

Copyright: Original content from this work may be used under the terms of the creative commons attributes 4.0 licence.

\title{
Analysis Of Domestic Violence And The Laws To Prevent Violence Against Women
}

\author{
Tishabaeva Lola Orifovna \\ Senior Lecturer, Department Of History Of Uzbekistan, Fergana Polytechnic Institute, \\ Fergana, Uzbekistan \\ Kodirova Dildora Sabirjonovna \\ Assistant, Department History Of Uzbekistan, Polytechnic Institute, Fergana, Uzbekistan
}

\section{ABSTRACT}

The article analyzes the relations between the democratic society and women in the Uzbek national values on the basis of existing laws. All cases of the law on crimes with the character of discrimination against women should be abolished. Trade with women and the elimination of all manifestations of the use of prostitution is established by the relevant law.

\section{KEYWORDS}

Family, society, violence, marriage, human rights, tradition.

\section{INTRODUCTION}

International legal acts on women's rights. One of such documents was signed by the UN General Assembly on November 7, 1967, No. 2263 (XXII) - in the "Declaration on the elimination of discrimination against women" adopted by resolution, discrimination against women leading to the denial or restriction of their equality with men is considered to be unfair in its essence and reflects the fact that it is a crime against human dignity, the existing laws, habits, decisions and practices considered discriminatory against women, the need to take all: 
The declaration states that the principle of equality of men and women should be included in the Constitution or guaranteed in a different way by law, that international instruments of the United Nations and specialized institutions on the elimination of discrimination against women should be ratified or acceded that they should be implemented as soon as possible. It is established that all appropriate measures should be taken with a view to eliminating concepts based on the idea that women are not full and to prepare public opinion for the termination of habits and other practices and to focus on national aspirations[1]. In declaration, all appropriate measures are taken to ensure that women have the right to vote in elections without any discrimination under the same conditions as men and the right to be elected to publicly elected bodies, the right to vote in all open referendums, the right to be in the public service and the right to perform all public functions.

These rights can be guaranteed by legislation, women have the same rights as men in obtaining, changing and maintaining their citizenship, which is considered one of the basic principles of a democratic society. Marriage with a foreigner does not have a direct effect on the citizenship of the wife, in particular, she can deprive her citizenship and force her husband to accept her citizenship.

\section{MATERIALS AND METHODS}

Without prejudice to the maintenance of the integrity and peace of the family, which remains the main cell of any society, married and unmarried women are equally entitled to men in the field of civil law. This can be explained by the examples below:

- The right to acquire and inherit property in the period of marriage or in other cases, as well as the right to manage, use and dispose of it.

- Equal rights and right of circulation;

- All appropriate measures, in principle, legislative measures, should be taken to ensure that individuals have the same rights as men, even in the legislation on migration.

All appropriate measures must be taken to ensure the principle of equality of the husband and wife status, including:

- Women should have the right to freely choose a spouse and enter into marriage only with his free and full consent, as men have;

- Women should have equal rights with men when they are in marriage and when they cancel it. In all cases, the interests of children should be prioritized;

- Parents should have equal rights and obligations to their children. In all cases, the interests of children should be prioritized.

- Children's marriages and girls should be prohibited from being engaged without regard to sexual maturity, and effective measures should be taken, including legislative measures, for the purpose of determining the minimum age of marriage and mandatory registration of marriage in the registration of civil cases.

All appropriate measures shall be taken to ensure equal rights with men to girls and and married and unmarried women in the field of education of all career, and in particular:

equal conditions for education and education in all types of educational institutions, including universities and vocational, technical and special schools;

the same educational programs, the same examinations, the composition of teachers, 
the same-quality classrooms and equipment, regardless of whether the educational institution is designed or intended to coeducate individuals of both sexes;

- Equal opportunities to receive scholarships and other benefits for education;

- Ehe next stage is an equal opportunity for educational programs, including adult education programs;

- Obtaining information of an educational nature with a view to facilitating the health and well-being of families;

Offences related to violation of women's rights. Such offences include, first of all, the violence committed against them. Violence is a physical, psychological exposure to a person is a threat to the life, health, sexual inviolability and freedom of a person.

Any violence against women is understood to be an act of harassment based on any sexual character, physical, sexual or mental assault on the health of a woman, or causing her suffering, as well as of committing acts that have been committed by a person or community deprived of freedom. This means that violence against women is in accordance with the employees listed below, but not limited to them:

- Physical, sexual and mental violence that takes place in the family, including rape, various heterogeneous operations that harm women and traditional officers observed in other types of life practices, as well as harassment that is outside of marriage and harassment that is associated with the abuse of women's chastity;

- Physical, sexual and mental violence that occupies a special place in society, including rape, coercion into sexual intercourse, and in workplaces, educational institutions and in places, extortion observed against women, intimidation, discrimination against them, selling women for prostitution and forcing them to prostitution;

- Regardless of where the physical, sexual and mental violence used against women occurs, whether it is from the side of the state or from the incompetence of the state, included in the discrimination of women. [2]

Family-marriage issues. Getting married in the life of the Uzbek family is the main event. His past life in his father's house is a preparation for him to become a bride, wife, mother. The folk proverb says that "Qiz bola birovning hasmidir".

\section{RESULT AND DISCUSSION}

A woman who is waiting for her husband in her house with endurance is the best. The initiative shown by the youth on the introduction of young people is condemned. If a girl declares that she herself has a choice in the family and wants to marry her, then in the family this will be rejected. It is desirable that acquaintance by habit was made through matchmakers. After the consent of the parents, the girls often go to a meeting, after which they must either confirm or refuse the choice of the parents. In most cases, the choice of parents will be decisive. In other words, women do not have personal freedom to make decisions when getting married. The basis of a very important life event for them is the desire of the parents, the choice of the parents. Women voluntarily undertake the right of choice in marriage to parents.

Traditional guidelines do not allow a girl to show her desire to marry or not. This is an 
obligation imposed on the girl by society, and she must fulfill this obligation as a duty against her will, feeling and willpower. And such behavior of women in the family is contrary to the Family Code.[3]

The right to be free from repression in the family. In relation to women in the family, the aunt can have different forms. Typhoid can occur in families, where it does not depend on their social status.

Harassment goes into such types of crime that the news about them rarely reaches the law enforcement agencies because the victims have filed complaints in many cases.

Experts do not consider women to be a social problem, because they do not marry people, who have become accustomed since childhood, who are in the era of gender stereotypes. No man, especially a woman, is not worthy of pressure, one practically does not care how the victim behaves, the suffering giver always finds a vacancy in his actions, tries to justify himself. There are many reasons that prevent women from going away from her husband, who gives suffering to her: the secret is to want her not to leave the house, to tell the mistress that happened to strangers, attachment from the economic side, lack of a place to go, not wanting to make her children laugh without a father, old customs - "what do people say" and other.

Equality of women and men in the family. All citizens of the Republic of Uzbekistan have the same rights and freedoms and equal before the law, regardless of sex, race, nationality, language, religion, social origin, nationality, personality and social status. The benefits are determined by the only law, the concentration must be in accordance with the social justice principals.[4]

\section{CONCLUSION}

Women occupy an indiscriminate place in the family. They add to their great contributions in the development of society and in the maintenance of the well -being of the family. The obligation to raise children requires the mutual distribution of parents, women and men in the society as a whole. In order for women to be equal partners with men in all spheres of life and development, it is necessary to appreciate girls from the very first age and to recognize the right to dignity of a person, to ensure their full enjoyment of their fundamental freedoms, including human rights.

\section{REFERENCES}

1. Article 3 in the "Declaration on the elimination of discrimination against women".

2. IV women's case world conference Action Program, item 113.

3. Family Code of the Republic of Uzbekistan Chapter 3, Part 2, Article 14.

4. Article 18 of the Constitution of the Republic of Uzbekistan. -T., 2018. 